\title{
Parasite Prevalence May Drive the Biotic Impoverishment of New England (USA) Bumble Bee Communities
}

\author{
Anne L. Averill ${ }^{1, *}$, Andrea V. Couto ${ }^{2}$, Jeremy C. Andersen ${ }^{1}\left(\mathbb{D}\right.$ and Joseph S. Elkinton ${ }^{1} @$ \\ 1 Department of Environmental Conservation, University of Massachusetts Amherst, \\ Amherst, MA 01003, USA; jcandersen@umass.edu (J.C.A.); elkinton@umass.edu (J.S.E.) \\ 2 Department of Computer Science, Bridgewater State University, Bridgewater, MA 02324, USA; \\ andrea.v.couto14@gmail.com \\ * Correspondence: averill@eco.umass.edu; Tel.: +1-413-545-1054
}

check for updates

Citation: Averill, A.L.; Couto, A.V.; Andersen, J.C.; Elkinton, J.S. Parasite Prevalence May Drive the Biotic Impoverishment of New England (USA) Bumble Bee Communities. Insects 2021, 12, 941. https:// doi.org/10.3390/insects12100941

Academic Editor: Cristina Botías

Received: 8 September 2021

Accepted: 13 October 2021

Published: 16 October 2021

Publisher's Note: MDPI stays neutral with regard to jurisdictional claims in published maps and institutional affiliations.

Copyright: (c) 2021 by the authors. Licensee MDPI, Basel, Switzerland. This article is an open access article distributed under the terms and conditions of the Creative Commons Attribution (CC BY) license (https:/ / creativecommons.org/licenses/by/ $4.0 /)$.
Simple Summary: Here we discuss widespread changes in the community structure of bumble bees (Bombus spp.) found in the coastal-zone community of New England. One species in particular, Bombus impatiens Cresson, 1863, has increased in relative abundance nearly $45 \%$ since the 1990 s to become the dominant species in the region, representing nearly $75 \%$ of all Bombus individuals collected in our studies. These changes in abundance may be, in part, due to differences in infection rates by microparasites, with $B$. impatiens having significantly fewer microparasites than several other less common and declining Bombus species. We discuss the possible role of microparasites in influencing the community composition of Bombus species in our region, and how these infections might be compounding declines in conjunction with habitat loss and climate change.

Abstract: Numerous studies have reported a diversity of stressors that may explain continental-scale declines in populations of native pollinators, particularly those in the genus Bombus. However, there has been little focus on the identification of the local-scale dynamics that may structure currently impoverished Bombus communities. For example, the historically diverse coastal-zone communities of New England (USA) now comprise only a few species and are primarily dominated by a single species, B. impatiens. To better understand the local-scale factors that might be influencing this change in community structure, we examined differences in the presence of parasites in different species of Bombus collected in coastal-zone communities. Our results indicate that Bombus species that are in decline in this region were more likely to harbor parasites than are B. impatiens populations, which were more likely to be parasite-free and to harbor fewer intense infections or co-infections. The contrasting parasite burden between co-occurring winners and losers in this community may impact the endgame of asymmetric contests among species competing for dwindling resources. We suggest that under changing climate and landscape conditions, increasing domination of communities by healthy, synanthropic Bombus species (such as B. impatiens) may be another factor hastening the further erosion of bumble bee diversity.

Keywords: Bombus; Crithidia; Nosema; pathogens; pollinator health; community ecology; competition

\section{Introduction}

Worldwide decline of bumble bee (Bombus spp. Latreille, 1802 [Hymenoptera: Apidae]) populations is ongoing reviewed in [1], and there is accumulating evidence that Bombus species may be particularly vulnerable to anthropogenic disturbances [2]. These shifts in diversity may pose a challenge to the functioning of many natural and agricultural ecosystems, where bumble bees are the predominant wild pollinators [3-5]. For example, wild bumble bees are by far the most abundant and effective pollinators of the New England (USA) cranberry crop, Vaccinium macrocarpon Aiton (Ericales: Ericaceae) [6-8], but the impoverishment of Bombus diversity in the Massachusetts growing region has been 
profound over the past half century. Henry J. Franklin, who completed a comprehensive revision of North American bumble bees published in 1913 [9], regularly observed nine species in the southeastern Massachusetts cranberry landscape [10]. However, five of these species are now rare or extirpated [8], and further declines in species evenness is ongoing. Our long-term surveys in southeastern Massachusetts began in 1990 [11] and used a repeated collection procedure at the same sites. We found that species loss is matched by the rapid increase in B. impatiens Cresson, 1863, with worker captures of $B$. impatiens now dominating all collections $[8,12]$. In our long-term survey, we also quantified bumble bee visits per minute at flowering cranberry beds in late spring-early summer and found that overall abundance has not declined [12]. It thus seems reasonable to conclude that $B$. impatiens, has backfilled vacated niche space of the lost species, and represents not only a greater relative abundance but also a greater absolute abundance in our surveyed communities.

Increases in the relative abundance of $B$. impatiens are not unique to the cranberry agroecosystem and have been documented across the northeastern United States [2,13,14]. This may be due to competition for forage and nest resources or emigration of imported cultures of $B$. impatiens into the surrounding natural landscapes. However, in a previous study in this system, Suni et al. [15] found no evidence of widespread introgression of alleles from commercial B. impatiens to wild bees and no evidence that commercial bumble bees were becoming established. There is increasing evidence that mass-reared commercial B. impatiens colonies imported to farms and greenhouses for pollination in the Pacific Northwest (USA) are responsible for the widespread observation of range expansion where B. impatiens is non-native [16]. In other regions, introduction of commercial European Bombus species, particularly Bombus terrestris L., 1758 for pollination services may be responsible for contraction and displacement of native species $[17,18]$. While the mechanism by which $B$. impatiens is replacing other species in our study region remains unknown, it is an adaptable, synanthropic species [19] that maintains large populations in many landscapes [20]. The species has a broad floral breadth, increased pesticide tolerance, and an early emergence coupled with a long flight season [5]. Our region has experienced warmer and wetter conditions than recorded historically, and that may accelerate extinction of some Bombus species [20]. On the other hand, large and widespread colonies of B. impatiens may be buffered from loss of genetic diversity and demographic stochasticity [21] and thus be resilient to the challenges posed by climate change. Finally, another factor that might be promoting the increased abundance of $B$. impatiens in this region is parasite load. Bombus individuals may be infected with a range of parasites (here the term parasite is used to include pathogens, parasites, and parasitoids) that have negative impacts on aspects of Bombus biology [22]. It has become a rule of thumb that higher prevalence of the microsporidia Nosema bombi Fanthan \& Porter is an indicator of species decline reviewed in [23]. However, the cause for varying Nosema levels among species is open to different interpretations. Species may naturally vary in susceptibility to the pathogen or alternatively, higher levels may be seen in isolated and inbred populations in decline [24]. However, in some European surveys, widespread and common species, such as $B$. terrestris and $B$. pascuorum (Scopoli), 1763, often are found with high microparasite infection reviewed in [25]. In addition to N. bombi, the trypanosomatid Crithidia bombi Lipa \& Triggiani has also been observed infecting species of Bombus [26-28]. Interestingly, this parasite is often associated with common Bombus species $[23,29]$, including B. impatiens, where in one study infection levels reached over $60 \%$ [29].

We initiated an intensive regional investigation of comparative prevalence of parasites in increasing vs. declining Bombus species. In this study, we quantified parasites seen in Bombus community members in the coastal-zone region of Massachusetts across the entire season of bumble bee activity. Members of this community included B. impatiens, as well as several species of Bombus that vary in conservation status [12, summarized in Table 1) including; B. vagans Smith, 1854 (in strong decline), B. griseocollis (DeGeer), 1773 (gradually increasing its distribution and abundance), B. bimaculatus Cresson, 1863 (apparently stable 
in distribution, but with variable abundance among years), and B. perplexus Cresson, 1863 (at the onset of decline). Based on our observations obtained over several years that B. impatiens was increasingly dominating survey samples and dissections seldom revealed intestinal pathogens compared to rarer species, we hypothesized that overall colony health of $B$. impatiens may also be a factor favoring rapid increase in populations.

Table 1. Changes in the percent of sites where species was collected (Percent Change) and relative abundance (Change in Abundance) revealed in a previously reported long-term survey (1990-2017) in our study region [11,12], and data from the present study showing the percent of sites where each species was collected (Percent of Sites), the total number of each species collected $(N)$, the percent of samples with microparasites (Percent Microparasites), the percent of samples with high-intensity infections (Percent High Intensity), and the percent of samples with multiple infections (Percent Mixed).

\begin{tabular}{|c|c|c|c|c|c|c|c|}
\hline Species & $\begin{array}{l}\text { Percent } \\
\text { Change }\end{array}$ & $\begin{array}{l}\text { Change in } \\
\text { Relative } \\
\text { Abundance }\end{array}$ & $\begin{array}{l}\text { Percent of } \\
\text { Sites }\end{array}$ & $N$ & $\begin{array}{l}\text { Percent Mi- } \\
\text { croparasites }\end{array}$ & $\begin{array}{l}\text { Percent High } \\
\text { Intensity }\end{array}$ & $\begin{array}{c}\text { Percent } \\
\text { Mixed }\end{array}$ \\
\hline Bombus griseocollis & +60 & +3.5 & 10.4 & 20 & 10.5 & 0 & 0 \\
\hline Bombus impatiens & +20 & +42.1 & 87.0 & 902 & 13.2 & 2.7 & 2.9 \\
\hline Bombus bimaculatus & +10 & -9.3 & 46.1 & 120 & 55.2 & 11.2 & 12.6 \\
\hline Bombus perplexus & -50 & -7.3 & 40.9 & 99 & 56.6 & 17.1 & 9.8 \\
\hline Bombus vagans & -60 & -10.4 & 21.7 & 61 & 52.5 & 17.0 & 14.5 \\
\hline
\end{tabular}

\section{Materials and Methods}

\subsection{Study Area}

We established 73 collection sites in southeastern Massachusetts, which encompassed forested, urban and suburban areas as well as ca. 5000 ha of cultivated cranberry (Figure 1). Only two sites were at cranberry farms, and there was no other significant agriculture in the region. The ca. $50 \mathrm{~km}^{2}$ sampled area was in two sub-ecoregions, Bristol Lowlands and Cape Cod and the Islands, within the Northeastern coastal zone. This zone has nearly no flower-rich grasslands or maintained meadows (favored by many Bombus spp. [1]) and is characterized by sandy and acidic soils that support Pinus rigida Mill. and Quercus ilicifolia Wangenh forests [30]. About half of the sites were located within the region's pine barrens, and as a result, the majority of flowering plants where bees were collected occurred near buildings, gardens, roadsides, and other public rights of way.

\subsection{Collections}

From 18 May to 4 November 2015, 2-3 trained collectors visited sites between the hours of 0900 and 1600 on days with no precipitation and with temperatures ranging from 22-30 ${ }^{\circ} \mathrm{C}$. Sampling was conducted at a site one to eight times over the season, and on average, four times. All but six of the sites were visited multiple times. For 10 min each, the collectors quickly moved among flower patches up to $100 \mathrm{~m}$ from the starting point to capture as many bees as possible in plastic vials. Bees were identified in the lab using keys in Williams et al., 2014 [19].

\subsection{Cryptic Bombus Identifications}

Recent work has shown that field identifications for three cryptic species of Bombus found in eastern North America (Bombus sandersoni Franklin, 1913, B. vagans, and B. perplexus) may not be possible without calculations of malar ratios or DNA barcoding [31]. To verify that our identifications for individuals identified as B. vagans were accurate, we obtained species-level identifications based on the amplification of a fragment of the mitochondrial locus cytochrome oxidase I (COI) for a subset of identified B. vagans individuals following the methods presented in [31]. Forward and reverse sequences were produced at the DNA Analysis Facility on Science Hill at Yale University, and the results edited in GeNeIOUs V. 11.1.2 (Biomatters Ltd., Auckland, New Zealand). Consensus sequences were compared to published sequences in the GenBank database using the 'blastn' algorithm implemented through https:/ /blast.ncbi.nlm.nih.gov/ (accessed on 17 March 2021). 

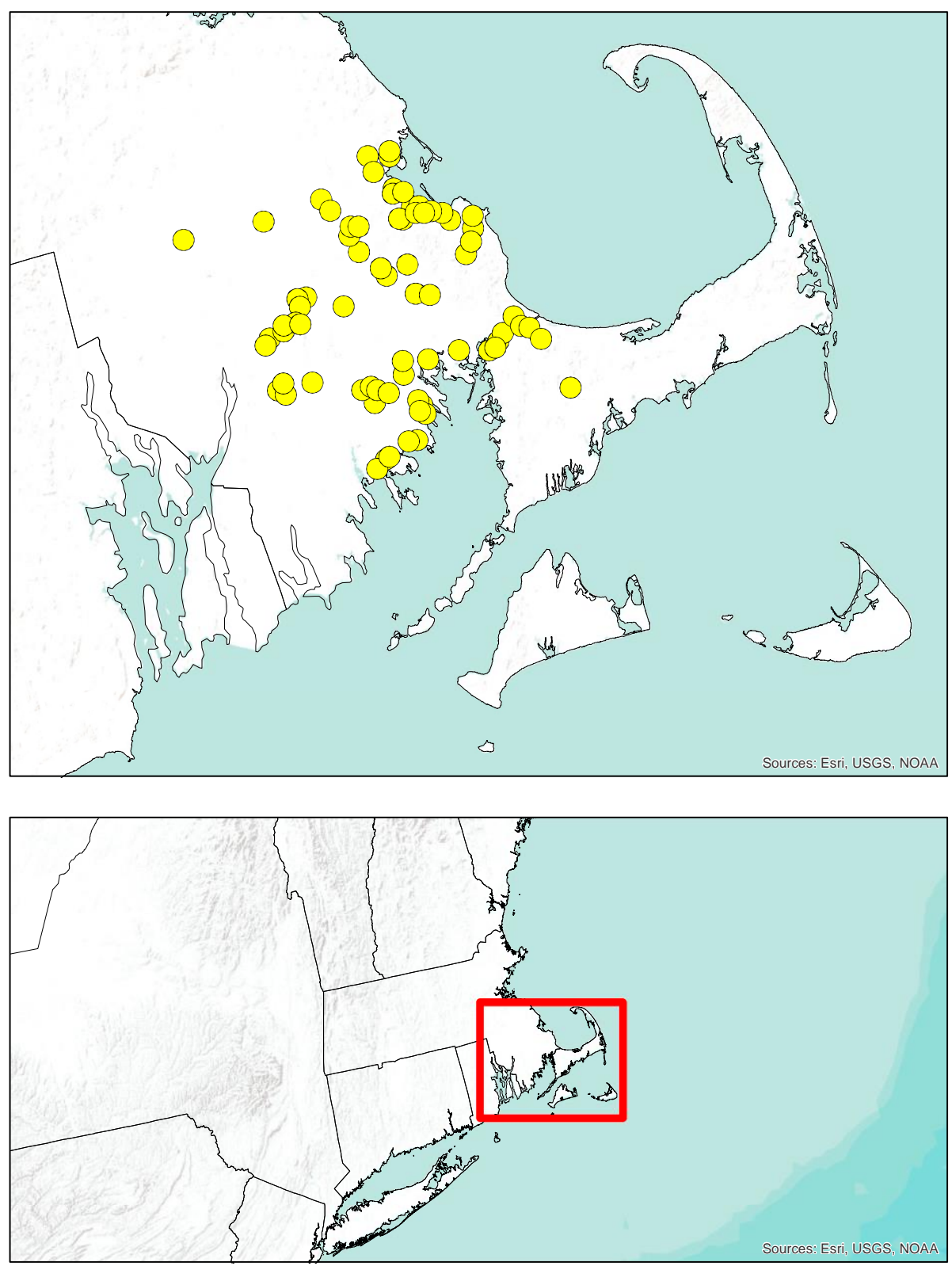

Figure 1. Map depicting collection locations (circles) of the 73 sites where Bombus workers and males were sampled across southeastern Massachusetts.

\subsection{Parasites and Their Assessment}

We quantified the presence of three intestinal microparasites based on visual examinations: microsporidia (Nosema sp.), neogregarines, and trypanosomes, as well as unidentified species of nematodes (Mermithidae), and an unidentified endoparasitic conopid fly (Diptera: Conopidae). In studies on susceptible European species, Nosema is considered a high impact parasite [22,32-34]. In contrast, trypanosomes such as C. bombi causes many sublethal effects [35-41]. Both C. bombi and N. bombi have been determined to be transmitted horizontally via an oral-fecal route, among flowers and within the colony [42-44], and while it is currently unknown, this is probably also true for neogregarines such as A. bombi [34]. The conopid parasitoid larvae were not reared out or identified, but previous studies conducted in this region identified all conopids as members of the genus Physocephala [29,45]. Similarly, to the results presented in Kissinger et al. [27], nematodes were only found at very low numbers; as such, they were not identified. 
To determine whether or not collected bees were infected, the presence of the different parasites described above was assessed through gut dissections. Prior to dissection, live bees were placed in a freezer until immobilized. The gut was then completely removed and inspected for conopid larvae and nematodes. To assess the intestinal microparasites, a mixture of gut fluids plus gut tissues and malpighian tubules were minced in $50 \mu \mathrm{L}$ of water on a microscope slide. Dissection tools were flame-sterilized between each sample, and the presence or absence of each parasite was quantified by randomly inspecting five visual fields on each slide under phase-contrast microscopy $(400 \times$ magnification). Because we chose to dissect the bees while alive on the day captured, to maximize efficiency, we determined high-intensity infections in a non-exacting manner by recording when one or more visual fields were flooded with cells or spores of a pathogen.

Prevalence, or the proportion of infected bees among all the bees examined, were compared by Fisher's Exact Test. Since male captures were low for all species except B. impatiens and B. bimaculatus, only workers were included for comparisons of parasite prevalence among species. A separate comparison was made between $B$. impatiens and $B$. bimaculatus males and workers. Because neogregarine and nematode infections were found infrequently, individuals with these two infections were pooled and comparisons were made between groups of bee species.

\section{Results}

\subsection{Collections}

A total of 1205 bumble bees were collected. All species overlapped in captures during a 1.5-month (June-July) period. In total, bees were collected from 58 flowering plants, with all five Bombus species collected while foraging on Rhododendron spp. and Nepeta $x$ faasenii, and four of the five species collected while foraging on Spirea japonica, Centaurea maculosa, and Salvia nemerosa. Field identifications found that the most abundant species was B. impatiens (74.9\% of the collection), followed by B. bimaculatus (9.9\%:), B. perplexus $(8.2 \%)$, B. vagans $(5.1 \%)$, and B. grisceocollis (1.7\%). Three B. fervidus (Fabricius) workers were also collected, historically a common species in the region $[9,46]$, but currently extremely rare [8]. Comparisons of these identifications to those obtained through DNA barcoding of 61 field identified $B$. vagans individuals resulted in the generation of clean sequence reads from 28 of the samples. All of the $B$. vagans identifications were confirmed with DNA barcoding (overall accuracy of identifications for this group was thus $100 \%$ ). DNA sequences generated in this study are available on GenBank (accession numbers OK044437-65).

\subsection{Parasites and Their Assessments}

Bombus impatiens individuals were more likely to be free of all parasites $(69.2 \%$ were parasite-free) when compared to B. bimaculatus, B. perplexus, and B. vagans, a grouping that was $43.4 \%$ parasite-free $(p<0.0001$; FET). Moreover, of the 54 bees with multiple parasites per individual, $B$. impatiens was least likely to harbor two or more parasite species (3.4\%) when compared to the prevalence of co-infections of B. bimaculatus $(9.4 \%, p=0.0083$; FET), B. perplexus $(11.1 \%, p=0.0018$; FET), and B. vagans $(15.3 \%, p=0.0004 ;$ FET). Looking at the three microparasites and across the collection, intense infections were recorded for 67 bees and the combined group of B. bimaculatus, B. perplexus, and B. vagans $(15.1 \%)$ was significantly more likely to have at least one intense infection compared to $B$. impatiens $(2.7 \%, p<0.0001 ; \mathrm{FET})$. Bombus griseocollis had no intense infections (Table 1).

For the three microparasite groups combined, $86.6 \%$ of $B$. impatiens workers and $89.5 \%$ of B. griseocollis were uninfected, while about half as many B. bimaculatus (45.8\%), B. perplexus $(43.3 \%)$, and B. vagans $(47.6 \%)$ were free of these pathogens (Table 1$)$. For individual pathogen prevalence (Table 2; Figure 2), B. impatiens individuals had significantly fewer trypanosomatid infections $(11.0 \%)$ than B. vagans $(32.2 \%)$, B. bimaculatus $(48.5 \%)$ and B. perplexus $(49.5 \%$ ) (for all comparisons with B. impatiens, $p<0.0001$; FET). Nosema infection levels for B. impatiens, B. bimaculatus and B. griseocollis were similar. While Nosema prevalence in B. impatiens $(4.7 \%)$ was lower than in B. perplexus $(11.1 \%)$, this difference was 
marginally significant ( $p=0.015 ; \mathrm{FET})$, in contrast to a comparison of Nosema infection of $B$. vagans $(20.3 \%)$, where the difference with $B$. impatiens was highly significant $(p<0.0001$; FET). No Nosema spores were observed in B. bimaculatus, even though a large sample of workers (107) was evaluated. For the three B. fervidus individuals collected, each was from a different site; two individuals were infected with Nosema, but with no other parasite.

Table 2. For each species, the numbers of workers and males collected (caste) during our surveys, including the percent of individuals infected with parasites. The prevalence of intense infections is shown in parentheses.

\begin{tabular}{|c|c|c|c|c|c|c|c|}
\hline Species & Caste & $N$ & $\begin{array}{l}\text { Percent try- } \\
\text { panosomatid }\end{array}$ & $\begin{array}{c}\text { Percent } \\
\text { neogre- } \\
\text { garine }\end{array}$ & $\begin{array}{l}\text { Percent } \\
\text { Nosema }\end{array}$ & $\begin{array}{l}\text { Percent } \\
\text { Conopid }\end{array}$ & $\begin{array}{c}\text { Percent } \\
\text { Nematode }\end{array}$ \\
\hline \multicolumn{8}{|c|}{ Pyrobombus subgenus } \\
\hline $\begin{array}{l}\text { Bombus } \\
\text { impatiens }\end{array}$ & Worker & 710 & $11.0(1.9)$ & $1.8(0.3)$ & $4.7(0)$ & 16.5 & 0.9 \\
\hline $\begin{array}{l}\text { Bombus } \\
\text { impatiens }\end{array}$ & Male & 192 & $2.1(1.0)$ & $0(0)$ & $1.1(0)$ & 2.6 & 0 \\
\hline $\begin{array}{c}\text { Bombus } \\
\text { bimaculatus }\end{array}$ & Worker & 107 & $48.6(9.1)$ & $9.4(0.9)$ & $0(0)$ & 6.5 & 4.7 \\
\hline $\begin{array}{c}\text { Bombus } \\
\text { bimaculatus }\end{array}$ & Male & 13 & $21.4(15.4)$ & $30.8(0)$ & $0(0)$ & 14.3 & 15.4 \\
\hline $\begin{array}{l}\text { Bombus } \\
\text { perplexus }\end{array}$ & Worker & 99 & $49.5(10.5)$ & $4.0(0)$ & $11.1(6.0)$ & 7.1 & 0 \\
\hline $\begin{array}{l}\text { Bombus } \\
\text { perplexus }\end{array}$ & Male & 0 & - & - & - & - & - \\
\hline $\begin{array}{l}\text { Bombus } \\
\text { vagans }\end{array}$ & Worker & 59 & $32.2(5.3)$ & $5.1(1.7)$ & $20.3(15.0)$ & 13.6 & 1.7 \\
\hline $\begin{array}{l}\text { Bombus } \\
\text { vagans }\end{array}$ & Male & 2 & $0(0)$ & $50.0(0)$ & $50.0(50)$ & 0 & 0 \\
\hline \multicolumn{8}{|c|}{ Cullumanobombus subgenus } \\
\hline $\begin{array}{l}\text { Bombus } \\
\text { griseocollis }\end{array}$ & Worker & 19 & $10.5(0)$ & $0(0)$ & $5.3(0)$ & 15.8 & 0 \\
\hline $\begin{array}{l}\text { Bombus } \\
\text { griseocollis }\end{array}$ & Male & 1 & - & - & - & - & - \\
\hline \multicolumn{8}{|c|}{ Thoracobombus subgenus } \\
\hline $\begin{array}{l}\text { Bombus } \\
\text { fervidus }\end{array}$ & Worker & 3 & $0(0)$ & $0(0)$ & $66.7(0)$ & 0 & 0 \\
\hline $\begin{array}{l}\text { Bombus } \\
\text { fervidus }\end{array}$ & Male & 0 & - & - & - & - & - \\
\hline
\end{tabular}

Neogregarines were detected in 30 workers (3.0\%) across the entire collection. Overall prevalence of neogregarines were significantly higher in B. bimaculatus $(9.35 \%)$ when compared to all other species pooled $(2.25 \%, p=0.008$; FET). In the sample of male B. bimaculatus, $30.8 \%$ were positive for neogregarines, and this was significantly higher than for workers $(9.4 \%, p<0.0001 ; \mathrm{FET})$. There were no differences between B. impatiens and B. griseocollis for any comparison among the parasites (Tables 1 and 2). Bombus vagans and B. perplexus harbored $15 \%$ and $6.9 \%$ intense Nosema infections, respectively, but high Nosema intensity was not observed in the three other species (Table 2). Intense trypanosomatid infections were observed in all species except $B$. griseocollis, ranging from $1.9 \%$ intense infections in B. impatiens to $9.1 \%$ and $10.5 \%$ in B. perplexus and B. vagans, respectively. 


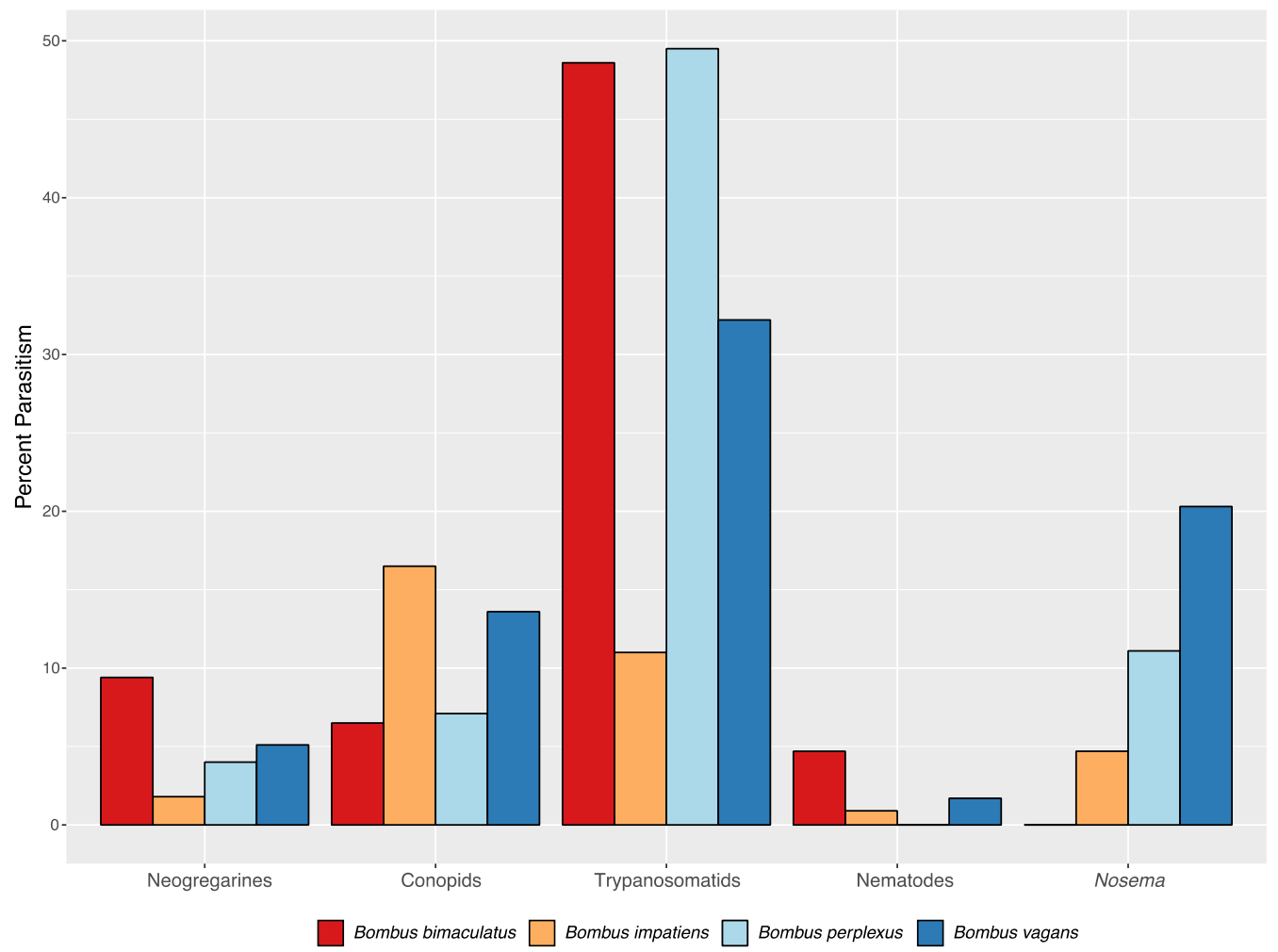

Figure 2. Percent infection of focal Bombus species workers by different parasite groups.

Although nematodes were dissected from only 13 bees $(1.3 \%)$, significantly more were recorded in B. bimaculatus $(4.7 \%)$ when compared to all other species combined $(0.9 \%$, $p=0.0084$; FET). Conopid prevalence over the season was $14.3 \%$. Prevalence of conopid larvae was significantly lower in the two earliest species, B. bimaculatus and B. perplexus $(6.8 \%)$ as compared to the combined later-season species B. griseocollis, B. impatiens and B. vagans $(16.2 \%, p=0.0003$; FET).

\section{Discussion}

The results presented here confirm that the rapidly increasing B. impatiens populations in our study region have considerably lower parasite burdens than species with steady or declining populations. Light parasite burden may prove to be a signal of continued regional expansion of another adaptable species; $B$. griseocollis was found to also be relatively parasite-free. Although historically absent in our study region, in past decades, B. griseocollis prevalence has been increasing [12], and this species is widespread elsewhere and is commonly reported in surveys of urban environments [17,47], isolated western MA meadows [29], and nearby regions such as an Atlantic coastal island [48]. With the exception of B. bimaculatus, where the parasite pattern differs somewhat from other species, the varying levels of parasites that we recorded are consistent with the species status derived from our long-term survey. Owing to their eusociality and frequency of monandry, when in decline, bumble bee species in isolated and fragmented populations are particularly at risk for inbreeding and loss of genetic diversity, and thus, may exhibit increased disease susceptibility $[49,50]$. We have lately seen a reduction in both distribution and prevalence of B. perplexus, and it will be instructive if the elevated pathogen load, particularly high-intensity microparasite infections, is an indicator of future decline. Of greater concern, the distribution and abundance of $B$. vagans have declined sharply in our collections, and this trend has been identified by other studies in northeast USA [2,5], and across North America (IUCN Red List http:/ / www.iucnredlist.org, accessed on 8 June 2017). For B. vagans, we found both high-intensity and mixed infections, as well 
as elevated infection levels of Nosema and trypanosomatids. This result is at odds with other studies that have not detected elevated N. bombi infections in B. vagans. For example, an extensive USA-wide survey did not detect Nosema in any B. vagans [28], and in a Maine survey, where B. vagans was abundant, prevalence of $N$. bombi was comparable to the levels across all species [51]. Regarding B. bimaculatus, studies have found that the abundance of this species is highly variable among survey years $[2,12,13]$-a trend that may be the result of the fact that $B$. bimaculatus is an early-season species and is thus more responsive to interannual variation in spring conditions and changes in floral resources. For B. bimaculatus, we saw elevated trypanosomatid prevalence compared to the levels observed in both B. impatiens and B. griseocollis. Resistance to trypanosomatid infection has been correlated with the composition of gut microbiota, with diversity and abundance of bacteria being important factors [52]. For example, in New Jersey (USA), Cariveau et al. [53] found that the microbiota differed in B. bimaculatus compared to co-distributed B. impatiens and B. griseocollis. Moreover, for B. bimaculatus, the assemblage of bacteria differed according to the bee's habitat, while this was not the case for B. impatiens and B. griseocollis. For B. bimaculatus in the present study, we saw significantly higher prevalence of both neogregarines and nematodes when compared to the pool of all other species. Although the nematode numbers were very low, we make no speculation regarding any aspect of their significance, but include them in this report to serve as a baseline for future parasite surveys. Surprisingly, we did not observe Nosema in any B. bimaculatus males or workers, even though individuals were collected at the same flowers as infected species. The worker sample was large, and individuals were collected across dozens of sites, suggesting that this species in this regional collection is resistant to Nosema [54].

All species at our study sites had medium tongue lengths (tongue length may partition Bombus species among available flowers) and were sharing a limited array of available flowers. Dissimilar parasite burdens (e.g., 2- to 4-fold differences in Nosema and trypanosomatid rates) may influence foraging performance and play a role in setting up winning and losing species that engage in asymmetric contests for pollen and nectar [1]. Individuals harboring high infection levels of trypanosomatids such as C. bombi, a parasite that is known to impair cognitive processes and thus impact foraging efficiency, could place colonies at a distinct disadvantage [35-41]. This possibility merits further study, as does likely competition among variously infected spring queens seeking to secure below-ground nests, particularly deserted rodent nests, a limiting resource [19,32,55]. In addition, future studies should utilize PCR-based approaches for obtaining species-level identifications of potential parasites, as PCR is both more sensitive for detecting parasite presence, and more accurate for species identifications [56-58].

Widespread acceptance that certain Bombus species declined as a result of exotic or native pathogen spillover from commercial Bombus colonies was based on circumstantial evidence from other regions [26,59]. Ready adoption of the theory was possible owing to three gaps in our baseline: (1) rarity of studies detailing comparative susceptibilities among North American Bombus species, (2) no historical baselines of parasite prevalence, and (3) lack of repeated measure surveys of relative and absolute abundances of Bombus at sites over time. Regarding the first gap, comparative susceptibilities remain largely unstudied. We are at a particular loss because the majority of research from which to draw is on European species or commercial mass-reared colonies. In this report, we addressed the second and third gaps and established a parasite baseline upon which we can overlay past shifts in community composition and to which we can refer in the future. It is unfortunate that such baselines were not carried out years earlier in order to understand the factors responsible for the drastic loss of bumble bee species in our region.

\section{Conclusions}

We investigated parasite loads in bumble bee communities where we have previously documented a regional shift in species composition. This shift has been accompanied by the gradual domination by a single species, $B$. impatiens, both in relative and absolute 
abundance. Much work has focused on the factors that may lead to pollinator decline, including exposure to pesticides, a lack of flowers, changing landscapes, changing climatic conditions, and especially, parasites. Less emphasis has been placed on determining why some species are thriving. We studied a key stressor, parasite load, by sampling communities throughout the season and across a region. Compared to congeners in decline, we documented a significantly lower microparasite load for the highly successful species, B. impatiens, and speculate that lower parasite burden in these flourishing colonies may produce stronger competitors for floral and nest resources, hastening the loss of community diversity.

Author Contributions: All authors contributed to the writing of this manuscript. Conceptualization, A.L.A. and A.V.C.; methodology, A.L.A. and J.C.A.; formal analysis, A.L.A. and J.C.A.; investigation, A.L.A. and A.V.C.; resources, A.L.A. and J.S.E. All authors have read and agreed to the published version of the manuscript.

Funding: This research was funded by USDA-NIFA-SCRI, grant number 2011-51181-30673 and USDA Multi-State Project number 1173 awarded to A.L.A.

Data Availability Statement: DNA sequence data are provided through GenBank (accession numbers OK044437-65).

Acknowledgments: We are grateful to Guang Xu for molecular confirmation of the genera that we designated in our microscopic identifications, Michael Veit for providing Bombus species confirmations, Lee Solter for a tutorial in Nosema biology and ID, Eva Goldwater for statistics consulting, and Jennifer Chandler for assistance formatting the manuscript. We would also like to thank two anonymous reviewers for their comments on an earlier version of this manuscript.

Conflicts of Interest: The authors declare no conflict of interest. The funders had no role in the design of the study; in the collection, analyses, or interpretation of data; in the writing of the manuscript, or in the decision to publish the results.

\section{References}

1. Goulson, D. Bumblebees Behaviour, Ecology, and Conservation, 2nd ed.; Oxford University Press: Oxford, UK, 2010.

2. Bartomeus, I.; Gibbs, J.S.; Danforth, B.N.; Wagner, D.L.; Hedtke, S.M.; Winfree, R. Historical changes in northeastern United States bee pollinators related to shared ecological traits. Proc. Natl. Acad. Sci. USA 2013, 110, 4656-4660. [CrossRef]

3. Dupont, V.L.; Damgarrd, C.; Simonsen, V. Quantitative historical change in bumblebee (Bombus spp.) assemblages of red clover fields. PLoS ONE 2011, 6, e25172. [CrossRef]

4. Bommarco, R.; Lundin, O.; Smith, H.G.; Rundlof, M. Drastic historic shifts in bumble-bee community composition in Sweden. Proc. R. Soc. Lond. B 2012, 279, 309-315. [CrossRef] [PubMed]

5. Jacobson, M.M.; Tucker, E.M.; Mathiason, M.E.; Rehan, S.M. Decline of bumble bees in northeastern North America, with special focus on Bombus terricola. Biol. Conserv. 2018, 217, 437-445. [CrossRef]

6. Cane, J.H.; Schiffhauer, D. Dose-response relationships between pollination and fruiting refine pollinator comparisons for cranberry (Vaccinium macrocarpon [Ericaceae]). Am. J. Bot. 2003, 90, 1425-1432. [CrossRef]

7. MacKenzie, K. The foraging behavior of honey bees (Apis mellifera L.) and bumble bees (Bombus spp.) on cranberry (Vaccinium macrocarpon Ait). Apidologie 1994, 25, 375-383. [CrossRef]

8. Averill, A.L.; Sylvia, M.M.; Hahn, N.; Couto, A.V. Bees (Hymenoptera: Apoidea) foraging on American Cranberry in Massachusetts. Northeast. Nat. 2018, 25, 501-512. [CrossRef]

9. Franklin, H.J. The Bombidae of the New World. Trans. Am. Entomol. Soc. 1913, 38, 177-486.

10. Franklin, H.J. Cranberry insects in Massachusetts: Part V. Insects and other animals beneficial in cranberry growing. Mass. Agric. Exp. Sta. Bull. 1950, 445, 55-76.

11. MacKenzie, K.E.; Averill, A.L. Bee (Hymenoptera: Apoidea) diversity and abundance on cranberry in southeastern Massachusetts. Ann. Entomol. Soc. Amer. 1995, 88, 334-341. [CrossRef]

12. Brown, E.R. Catastrophic Loss of Bumble Bee (Bombus spp.) Diversity Revealed in 27-Year Survey of Massachusetts Cranberry Pollinators. Bachelor's Thesis, Commonwealth Honors College, University of Massachusetts Amherst, Amherst, MA, USA, 2018.

13. Colla, S.R.; Gadallah, F.; Richardson, L.; Wagner, D.; Gall, L. Assessing decline of North American bumble bees (Bombus spp.) using museum specimens. Biodivers. Conserv. 2012, 21, 3585-3595. [CrossRef]

14. Tucker, E.M.; Rehan, S.M. Wild bee pollination networks in northern New England. J. Insect Conserv. 2016, 20, 325-337. [CrossRef]

15. Suni, S.S.; Scott, Z.; Averill, A.L.; Whitely, A. Population genetics of wild and managed pollinators: Implications for crop pollination and the genetic integrity of wild bees. Conserv. Genet. 2017, 18, 667-677. [CrossRef] 
16. Looney, C.; Strange, J.P.; Freeman, M.M.; Jennnings, D. Expansion of Bombus impatiens Cresson in the Pacific Northwest and its establishment in Washington State. Biol. Invasions 2019, 21, 1879-1885. [CrossRef]

17. Inoue, M.N.; Yokoyama, J. Competition for flower resources between Bombus terrestris (L.) and Japanese native bumblebees. Appl. Entomol. Zool. 2010, 45, 29-35. [CrossRef]

18. Morales, C.L.; Arbetman, M.P.; Cameron, S.A.; Aizen, M.A. Rapid ecological replacement of a native bumble bee by invasive species. Front. Ecol. Environ. 2013, 11, 529-534. [CrossRef]

19. Williams, P.H.; Thorpe, R.W.; Richardson, L.L.; Colla, S.R. Bumble Bees of North America: An Identification Guide; Princeton University Press: Princeton, NJ, USA, 2014.

20. Soroye, P.; Newbold, T.; Kerr, J. Climate change contributes to widespread declines among bumble bee species across continents. Science 2020, 367, 685-688. [CrossRef]

21. Novotny, J.L.; Reeher, P.; Varvaro, M.; Lybbert, A.; Smith, J.; Mitchell, R.J.; Goodell, K. Bumble bee species distributions and habitat associations in the Midwestern USA, a region of declining diversity. Biodivers. Conserv. 2021, 30, 865-887. [CrossRef]

22. Schmid-Hempel, P. Parasites in Social Insects; Princeton University Press: Princeton, NJ, USA, 1988.

23. Malfi, R.L.; Roulston, T.H. Patterns of parasite infection in bumble bees (Bombus spp.) of Northern Virginia. Ecol. Entomol. 2014, 39, 17-29. [CrossRef]

24. Brown, M.J.F. The trouble with bumblebees. Nature 2011, 469, 169-170. [CrossRef] [PubMed]

25. Goulson, D.; Whitehorn, P.; Fowley, M. Influence of urbanization on the prevalence of protozoan parasites of bumblebees. Ecol. Entomol. 2012, 37, 83-89. [CrossRef]

26. Cameron, S.A.; Lim, H.C.; Lozier, J.D.; Duennes, M.A.; Thorp, R. Test of the invasive pathogen hypothesis of bumble bee decline in North America. Proc. Natl. Acad. Sci. USA 2016, 113, 4386-4391. [CrossRef] [PubMed]

27. Kissinger, C.N.; Cameron, S.A.; Thorp, R.W.; White, B.; Solter, L.F. Survey of bumble bee (Bombus) pathogens and parasites in Illinois and selected areas of northern California and southern Oregon. J. Invertebr. Pathol. 2011, 107, 220-224. [CrossRef] [PubMed]

28. Cordes, N.; Huang, W.-F.; Strange, J.P.; Cameron, S.A.; Griswold, T.L.; Lozier, J.D.; Solter, L.F. Interspecific geographic distribution and variation of the pathogens Nosema bombi and Crithidia species in United States bumble bee populations. J. Invertebr. Pathol. 2012, 109, 209-216. [CrossRef] [PubMed]

29. Gillespie, S. Factors affecting parasite prevalence among wild bumblebees. Ecol. Entomol. 2010, 35, 737-747. [CrossRef]

30. Hall, B.; Motzkin, G.; Foster, D.R.; Syfert, M.; Burk, J. Three hundred years of forest and land-use change in Massachusetts, USA. J. Biogeogr. 2002, 29, 1319-1335. [CrossRef]

31. Milam, J.; Johnson, D.E.; Andersen, J.C.; Fassler, A.B.; Narango, D.L.; Elkinton, J.S. Validating morphometrics with DNA barcoding to reliably separate three cryptic species of Bombus Cresson (Hymenoptera: Apidae). Insects 2020, 11, 669. [CrossRef]

32. Otti, O.; Schmid-Hempel, P. A pollinator parasite with detrimental fitness effects. J. Invertebr. Pathol. 2007, 96, 118-124. [CrossRef]

33. Rutrecht, S.T.; Brown, M.J.F. Differential virulence in a multiple-host parasite of bumble bees: Resolving the paradox of parasite survival? Oikos 2009, 118, 941-949. [CrossRef]

34. Graystock, P.; Meeus, I.; Smagghe, G.; Goulson, D.; Hughes, W.O.H. The effects of single and mixed infections of Apicystis bombi and deformed wing virus in Bombus terrestris. Parasitology 2016, 143, 358-365. [CrossRef]

35. Brown, M.J.F.; Schmid-Hempel, R.; Schmid-Hempel, P. Strong context-dependent virulence in a host-parasite system: Reconciling genetic evidence with theory. J. Anim. Ecol. 2003, 72, 994-1002. [CrossRef]

36. Shykoff, J.A.; Schmid-Hempel, P. Incidence and effects of four parasites in natural populations of bumble bees in Switzerland. Apidologie 1991, 22, 117-125. [CrossRef]

37. Brown, M.J.F.; Loosli, R.; Schmid-Hempel, P. Condition-dependent expression of virulence in a trypanosome infecting bumblebees. Oikos 2000, 91, 421-427. [CrossRef]

38. Gegear, R.J.; Otterstatter, M.C.; Thomson, J.D. Does parasitic infection impair the ability of bumblebees to learn flower-handling techniques? Anim. Behav. 2005, 70, 209-215. [CrossRef]

39. Gegear, R.J.; Otterstatter, M.C.; Thomson, J.D. Bumble-bee foragers infected by a gut parasite have an impaired ability to utilize floral information. Proc. R. Soc. B 2006, 273, 1073-1078. [CrossRef]

40. Otterstatter, M.C.; Gegear, R.J.; Colla, S.; Thomson, J.D. Effects of parasitic mites and protozoa on the flower constancy and foraging rate of bumble bees. Behav. Ecol. Sociobiol. 2005, 58, 383-389. [CrossRef]

41. Goulson, D.; O'Connor, S.; Park, K.J. The impacts of predators and parasites on wild bumblebee colonies. Ecol. Entomol. 2018, 43, 163-181. [CrossRef]

42. Alford, D.V. Bumblebees; Davis-Poynter: London, UK, 1975.

43. Schmid-Hempel, P.; Schmid-Hempel, R. Transmission of a pathogen in Bombus terrestris, with a note on division of labor in social insects. Behav. Ecol. Sociobiol. 1993, 33, 319-327. [CrossRef]

44. Durrer, S.; Schmid-Hempel, P. Shared use of flowers leads to horizontal pathogen transmission. Proc. R. Soc. Lond. B 1994, 258, 299-302.

45. Smith, K.G.; Peterson, B.V. Conopidae. In Manual of Nearctic Diptera; McAlpine, J.F., Peterson, B.V., Shewall, G.E., Teskey, H.H., Vockeroth, J.R., Wood, D.M., Eds.; Research Branch Agriculture Canada: Ottawa, ON, Canada, 1987; Volume 2, pp. 749-756.

46. Plath, O.E. Bumblebees and Their Ways; Macmillan Co.: New York, NY, USA, 1934. 
47. Matteson, K.C.; Ascher, J.S.; Lancellotto, G.A. Bee richness and abundance in New York City urban gardens. Ann. Entomol. Soc. Am. 2008, 101, 140-150. [CrossRef]

48. Ascher, J.S.; Kornbluth, S.; Geolet, R.G. Bees (Hymenoptera: Apoidea: Anthophila) of Gardiners Island, Suffolk County, New York. Northeast. Nat. 2014, 21, 47-71. [CrossRef]

49. Whitehorn, P.R.; Tinsley, M.C.; Brown, M.J.F.; Darvill, B.; Goulson, D. Genetic diversity, parasite prevalence and immunity in wild bumblebees. Proc. R. Soc. B 2011, 278, 1195-1202. [CrossRef]

50. Woodward, S.H.; Lozier, J.D.; Goulson, D.; Williams, P.H.; Strange, J.P.; Jha, S. Molecular tools and bumble bees: Revealing hidden details of ecology and evolution in a model system. Mol. Biol. 2015, 24, 2916-2936. [CrossRef]

51. Bushman, S.L.; Drummond, F.A.; Beers, L.A.; Groden, E. Wild bumblebee (Bombus) diversity and Nosema (Microsporidia: Nosematidae) infection levels associated with lowbush blueberry (Vaccinium angustifloium) production and commercial bumblebee pollinators. Psyche J. Entomol. 2012, 2012, 429398.

52. Mockler, B.K.; Kwong, W.K.; Moran, N.A.; Koch, H. Microbiome structure influences infection by the parasite Crithidia bombi in bumble bees. Appl. Environ. Microbiol. 2018, 84, e2335-17. [CrossRef]

53. Cariveau, D.P.; Powell, J.E.; Koch, H.; Winfree, R.; Moran, N.A. Variation in gut microbial communities and its association with pathogen infection in wild bumble bees (Bombus). ISME J. 2014, 8, 2369-2379. [CrossRef] [PubMed]

54. Ayres, J.S.; Schneider, D.S. Two ways to survive an infection: What resistance and tolerance can teach us about treatments for infectious diseases. Nat. Rev. Immunol. 2008, 8, 88-895.

55. McFrederick, Q.S.; LeBuhn, G. Are urban parks refuges for bumble bees Bombus spp. (Hymenoptera:Apidae)? Biol. Conserv. 2005, 129, 372-382. [CrossRef]

56. Blaker, E.A.; Strange, J.P.; James, R.R.; Monroy, F.P.; Cobb, N.S. PCR reveals high prevalence of non/low sporulating Nosema bombi (microsporidia) infections in bumble bees (Bombus) in Northern Arizona. J. Invert. Pathol. 2014, 123, 25-33. [CrossRef] [PubMed]

57. Barolome, C.; Buendia, M.; Benito, M.; De la Rua, P.; Ornosa, C.; Martin-Hernandez, R.; Higes, M.; Maside, X. A new multiplex PCR protocol to detect mixed trypanosomatid infections in species of Apis and Bombus. J. Invert. Pathol. $2018,154,37-41$. [CrossRef] [PubMed]

58. Tripodi, A.D.; Szalanski, A.L.; Strange, J.P. Novel multiplex PCR reveals multiple trypanosomatid species infecting North American bumble bees (Hymenoptera: Apidae: Bombus). J. Invert. Pathol. 2018, 153, 147-155. [CrossRef]

59. Cameron, S.A.; Lozier, J.D.; Strange, J.P.; Koch, J.B.; Cordes, N.; Solter, L.F.; Griswold, T.L. Patterns of widespread decline in North American bumble bees. Proc. Natl. Acad. Sci. USA 2011, 108, 662-667. [CrossRef] 